\title{
Monosotic fibrous dysplasia and solitary intramuscular myxoma of the head and neck: A unique presentation of Mazabraud's syndrome and a literature review
}

\author{
SHUITING FU, ZHUOWEI TIAN, CHENPING ZHANG and YUE HE \\ Department of Oral and Maxillofacial Head and Neck Surgery, Shanghai 9th People's Hospital, \\ Shanghai Jiao-Tong University School of Medicine, Shanghai 200011, P.R. China
}

Received September 16, 2014; Accepted June 5, 2015

DOI: $10.3892 / 01.2015 .3633$

\begin{abstract}
Mazabraud's syndrome (MS) is a rare disease that is a combination of fibrous dysplasia and intramuscular myxomas. MS is a benign lesion and there is little data on the disease due to its low incidence. In the present study, the case of a 38-year-old patient who presented with a soft-tissue mass involving the masseter and swelling at the mandibular body and mandibular ramus is reported. Since the mandible is an important aesthetic and functional organ in the oral and maxillofacial region, surgery was primarily aimed at resecting the tumor, with good safety margins, and reconstructing the resultant defect. The lesions were pathologically diagnosed as MS. The unique features of this case included the painless and monostotic fibrous dysplasia, the solitary intramuscular myxomas involving the jaw and the male gender of the patient. MS usually occurs in the lower extremities, with an unusual predilection for the right limb; however, it rarely occurs in the head and neck region. A retrospective analysis of the clinical features and management of MS was also performed in the present study, together with a literature review. From the literature, it was concluded that the incidence of MS is $\sim 2.3$-fold greater in female patients than in male patients, and that the age of onset of MS ranges between 17 and 82 years, with an average age of 46.25 years.
\end{abstract}

\section{Introduction}

Mazabraud's syndrome (MS) is a rare benign syndrome that is reported to be associated with single or multiple intramuscular myxomas and fibrous dysplasia occurring in a single or

Correspondence to: Professor Yue He, Department of Oral and Maxillofacial Head and Neck Surgery, Shanghai 9th People's Hospital, Shanghai Jiao-Tong University School of Medicine, 639 Zhi Zao Ju Road, Shanghai 200011, P.R. China

E-mail: william5218@126.com

Key words: Mazabraud's syndrome, fibrous dysplasia, intramuscular myxomas, mandible multiple bones. Intramuscular myxoma in itself is a relatively uncommon benign mesenchymal tumor (1), while fibrous dysplasias are more frequent benign lesions (2). To the best of our knowledge, 92 cases of MS have been reported in the medical literature thus far. However, only 9 cases have reported the combination of a solitary myxoma and monostotic fibrous dysplasia (3-10). MS involving the mandible and the adjacent soft tissue of the bone lesions was reported by Logel (11). However, MS of the masseter and the mandible are rarely reported compared with other regions. The aim of the current study was to present a novel case of solitary myxoma and monostotic fibrous dysplasia involving the jaw and the masseter. Additionally, an overview of the 92 reported cases of MS is also presented.

\section{Case report}

On February 8th, 2014, a 38-year-old male patient presented to the Shanghai Ninth People's Hospital (Shanghai, China) with a history of a slowly growing painless swelling in the left mandibular area that had been present for 23 years. A definitive diagnosis had not been reached upon examination at a local hospital (Zhengzhou, China) in 2011. The patient had undergone a pathological biopsy prior to the current examination and was diagnosed with ossifying fibroma in another hospital (Zhongshan Hospital, Zhengzhou, China). The current physical examination identified two masses, one on the left mandible and one on the left musculus buccinator. The left mandibular lump measured $\sim 5 \mathrm{~cm}$ in diameter, was hard in nature and protruded from the surface with ill-defined margins. There was no visible disease activity and no palpable tenderness. The soft-tissue swelling located in the musculus buccinator near the left mandibular measured $\sim 3 \mathrm{~cm}$ in diameter; the lesion exhibited no visible ulceration and no palpable tenderness (Fig. 1). Conventional panoramic radiography demonstrated a hazy shadow of low but uneven density, often with ill-defined margins in the mandible. The patient did not present with any bony deformities or café-au-lait spots. Computed tomography (CT) and three-dimensional $\mathrm{CT}$ reconstruction in the oral and maxillofacial regions showed that the mass exhibited a localized 'ground-glass' pattern on the left mandibular body and mandibular ramus, and an uneven high-density shadow 
A

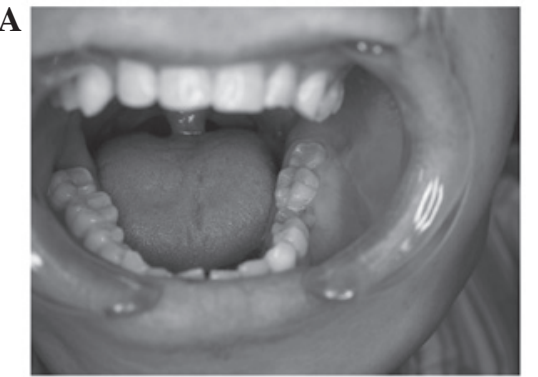

B
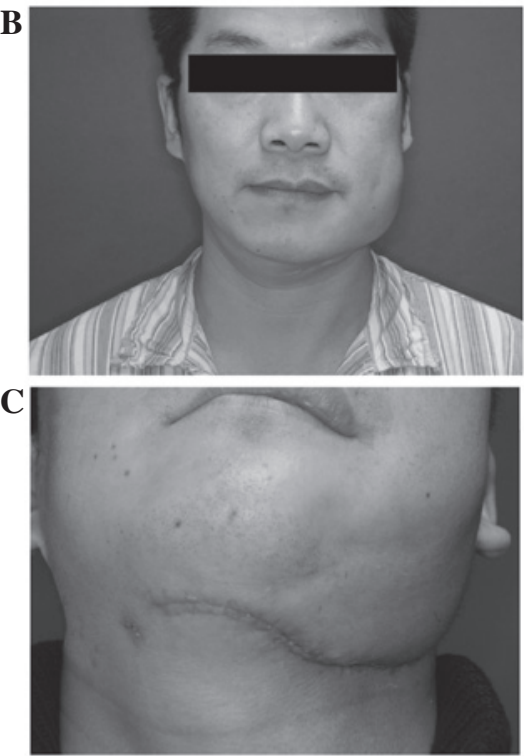

D

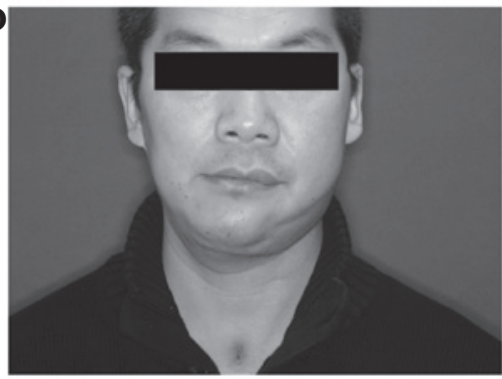

Figure 1. (A) Pre-operative intraoral view of the mass located in the left jaw. (B and C) Frontal view of the patient at 1 week post-surgery demonstrating swelling of the left side of the jaw. (D) Frontal view showing no marked contour defect of the jaw at 3 months post-surgery.

was identified (Fig. 2). The buccal bone cortex of the mass was discontinuous. Adjacent soft tissue was markedly thickened, with uniform density.

A pre-operative diagnosis of single intramuscular myxoma and a benign bone lesion was determined and histopathologically confirmed following resection of the lesions. The left mandible lesions and outermost region of the bony plates of the ramus were completely resected, while conserving the condyle. Next, a free fibular osteocutaneous flap with skin island reconstruction was performed. During the surgery, a soft-tissue mass of $3.5 \times 2.5 \times 1.0 \mathrm{~cm}$ was resected. Histological examination of the left mandibular lesions showed immature woven bone trabeculae devoid of osteoblastic lining laid in proliferative fibrous connective tissue, and the lesions were characterized by some mucous degeneration and were hypercellular enough to be characterized as fibrous dysplasia. The histopathological examination of the buccal mass revealed a tumor extending

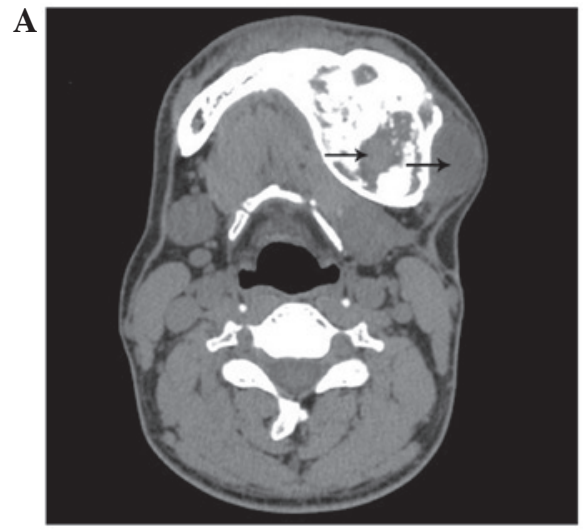

$\mathbf{B}$

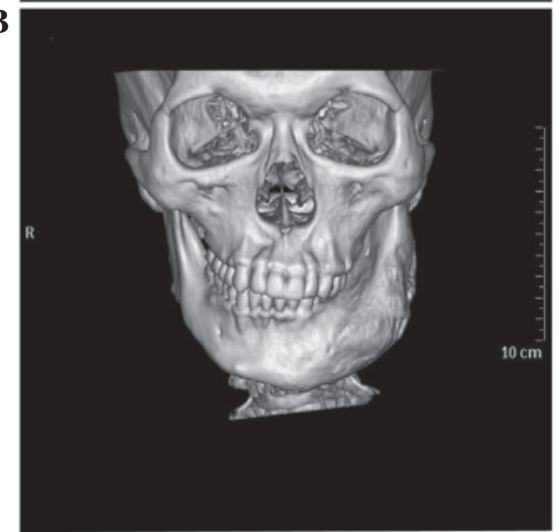

C

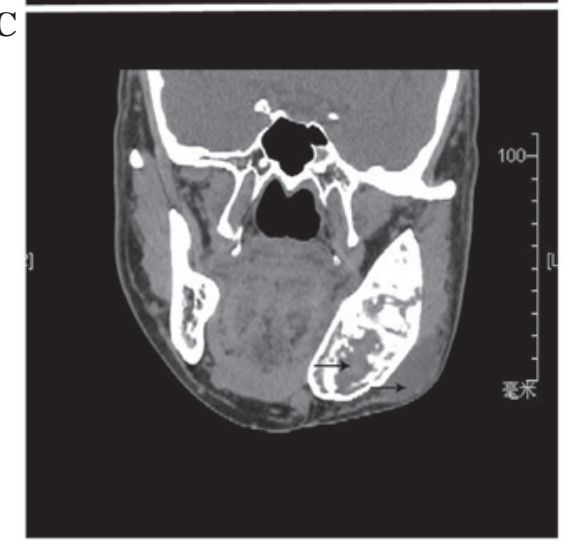

Figure 2. (A) Coronal computed tomography (CT) in the oral and maxillofacial regions showing a solid soft-tissue mass within the left musculus buccinator (right arrow) and radiolucent cystic lesions with frosted glass margins in the left body of the mandible (left arrow) (B) Three dimensional $\mathrm{CT}$ reconstruction in the oral and maxillofacial regions showing bone widening and local destruction of the adjacent cortex. (C) Axial CT in the oral and maxillofacial regions showing a solid soft tissue mass within the left musculus buccinator (right arrow) and radiolucent cystic lesions with frosted glass margins in the left body of the mandible (left arrow).

into the striated muscle, formed from hypocellular tissue with bland stellate cells and spindle-shaped cells within a polysaccharide abundant myxoid matrix. A histopathological diagnosis of intramuscular myxoma was formed. Immunohistochemical analysis showed positive staining for vimentin and cluster of differentiation (CD) 99 , and negative staining for desmin, smooth muscle actin, B-cell lymphoma-2, S-100 protein and CD34. The intramuscular myxoma with adjacent fibrous dysplasia was diagnosed as MS (Fig. 3). Follow-up examinations were planned every 3-6 months for 3 years. Three and six months after surgery, MRI follow-up examinations revealed that the 

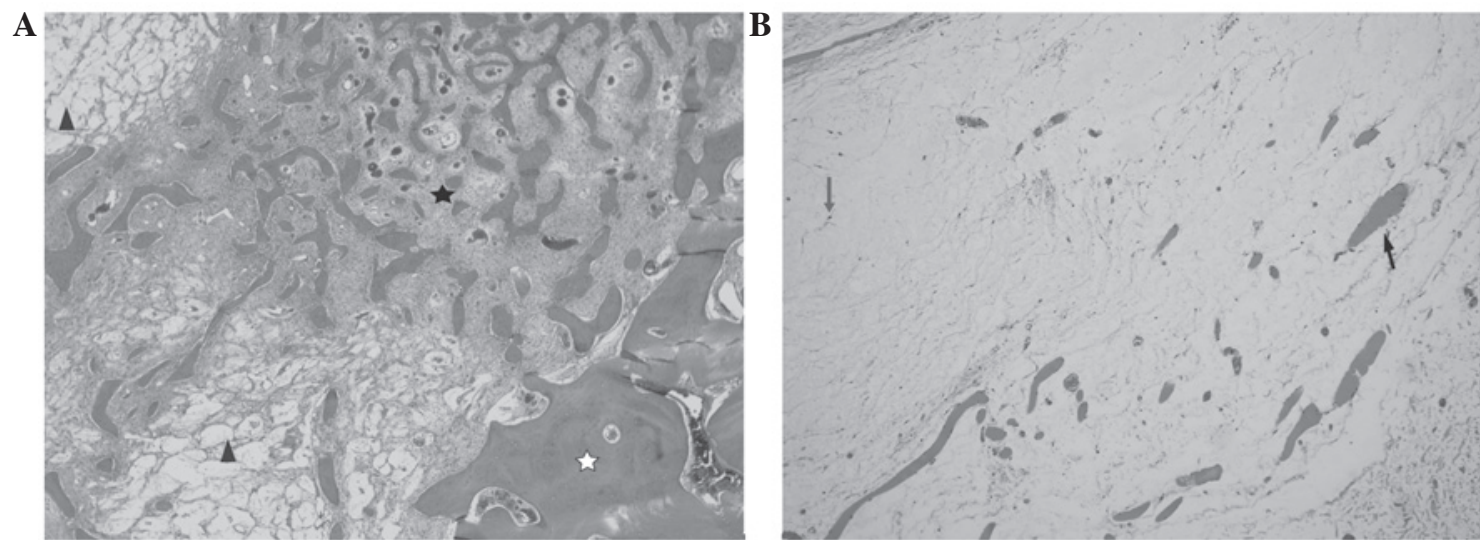

Figure 3. (A) Histological specimen showing fibrous dysplasia composed of immature woven bone trabeculae devoid of osteoblastic lining (black star) and the lesions of segmental myxoid (black triangle) and normal bone (white star) tissues (hematoxylin and eosin; original magnification, x40). (B) Histological specimen showing the myxoma (grey arrow) with a well-defined border and the adjacent skeletal muscle (black arrow) (hematoxylin and eosin; original magnification, $\mathrm{x} 100)$.

patient exhibited no clear evidence of recurrence of myxoma and fibrous dysplasia. However, the patient has subsequently been lost to follow-up.

This study was approved by the Shanghai Ninth People's Hospital Institutional Review Board and the patient provided written informed consent.

\section{Discussion}

MS was first described in the German literature by Henschen in 1926 (12), and Mazabraud et al presented a pattern of association between fibrous dysplasia and soft-tissue myxomas in in 1967 (13). Only a limited number of cases appear in the literature. Not including the present case, $\sim 92$ cases of what has come to be termed as 'Mazabraud's syndrome' have been described in the literature to date (Table I) (3,5-75).

MS is an uncommon type of benign tumor that mainly occurs in the lower limbs (14). In the most extensive review of MS to date in the literature, the present study found 9 cases of the unusual association of monostotic fibrous dysplasia combined with a rare solitary myxoma. A mandiblular origin accounted for $\sim 10$ cases.

Six of these cases were excluded from the study because we were not get detailed information $(3,6,9,15-17)$, therefore, including the present case, a total of 87 cases were reviewed. Table I reveals that the majority of affected patients were female (61 cases). While only 26 cases were male, indicating an $\sim 2.3$-fold greater incidence in females than in males. The most common onset of fibrous dysplasia is polyostotic, present in 70 cases $(80.46 \%)$. In 17 cases, fibrous dysplasia was monostotic (19.54\%). However, these myxomas were solitary in 40 cases $(45.98 \%)$. Monostotic fibrous dysplasia and solitary myxoma, when associated, is a rare condition. Only a few cases were mentioned in the literature. Another common finding of MS that was recorded in the literature was its localization in the lower extremities, which occurred in $82.71 \%$ of cases (67 in the lower extremities, 35 in the upper extremities, 19 in all four extremities and in 11 in the head and neck; in 6 cases, detailed information was not recorded). These tumors were bilateral in 30 cases and unilateral in 51 cases. This finding is in agreement with other studies, which confirm that the majority patients with MS have multiple intramuscular myxomas and polyostotic fibrous dysplasia that tend to be located in the lower extremities, with a particular predilection for the lower right limb (18). The age of onset of MS in the 87 patients studied ranged between 17 and 82 years, with an average age of 46.25 years. MS was most commonly diagnosed in the middle-aged population.

The case reported in the present study differs from the majority of the previously reported cases due to its rare localization in the head and neck, specifically the mandible, in addition to the unusual association of monostotic fibrous dysplasia and solitary myxoma. As the mandible is an important aesthetic and functional organ in the oral and maxillofacial region, an accurate pre-operative estimation of mandibular invasion remains challenging.

Another unusual aspect of the present study was the complex appearance of histopathological findings of the mucous degeneration of fibrous dysplasia. It is rare to find the mucous transformation of fibrous dysplasia that was observed in this case in patients with MS. Although uncommon, malignant transformation of fibrous dysplasia can also occur in patients with MS (76).

Intramuscular myxomas are rare benign tumors of the musculoskeletal system that were first recognized as a definite clinicopathologic entity by Enzinger in 1965. The study presented a brief compilation of 34 examples of intramuscular myxoma and demonstrated the benign clinical course of the tumor, as relatively few of the cases exhibited a tendency to metastasize (77). While intramuscular myxoma is rare, fibrous dysplasia is not. Fibrous dysplasia is a congenital disease characterized by a condition affecting one, several or numerous bones, leading to osteolytic lesions, deformities and fractures (78). Intramuscular myxoma is usually a solitary lesion, and exhibits an association with multiple fibrous dysplasia (19). Occasionally, MS is associated with McCune-Albright syndrome (MAS) (20). MAS is a rare syndrome with the three combinated characteristics of polyostotic fibrous dysplasia, endocrine dysfunction and café-au-lait spots (79). 
Table I. Reported cases of Mazabraud's syndrome.

Details of lesion

First author/s, year (ref.)

Gender Age, years

Fibrous dysplasia

Myxoma

Lesion localization

Henschen, 1926 (12)
Krogius, 1929 (23)

Uehlinger, 1940 (24)

Braunchwarth, 1953 (5)

Mazabraud and Girard, 1957 (25)

Heinemann and Woerth, 1958 (26)

Laporte, 1961 (27)

Lick, 1962 (28)

Mazabraud, 1967 (13)

Roze, 1967 (29)

Semat, 1969 (30)

Wirth et al, 1971 (31)

Lejeune, 1972 (32)

Ireland, 1973 (33)

Logel, 1976 (11)

Berkhoff, 1981 (6)

Sedmak, 1983 (34)

Lever and Pettingale, 1983 (35)

Segev and Reiner, 1985 (3)

Witkin, 1986 (36)

Blasier, 1986 (37)

Biagini, 1987 (38)

Glass-Royal, 1989 (39)

Sundaram, 1989 (40)

Gianoutsos, 1990 (41)

Prayson, 1992 (42)

Gober and Nicholas, 1993 (43)

Aoki, 1995 (44)

Fujii, 1996 (45)

Limouzy, 1996 (7)

Court-Payen, 1997 (46)

Szendroi, 1998 (22)

Cabral, 1998 (47)

Lopez-Ben, 1999 (21)

Thomacot, 1999 (48)

Walker, 1999 (49)

Kransdorf and Murphey, 1999 (50)

Okamoto, 2000 (51)

Struk, 2000 (8)

Faivre, 2001 (52)

Delabrousse, 2001 (53)

Pollandt, 2002 (54)

$\begin{array}{cc}\text { Female } & 66 \\ \text { Female } & 26 \\ \text { Male } & 67 \\ \text { Female } & 5 \\ \text { Male } & 5 \\ \text { Female } & 8 \\ \text { Female } & 2 \\ \text { Male } & 5\end{array}$

Female

Female $\quad 38$

Male $\quad 47$

Male $\quad 17$

Male 33

Male 41

Female $\quad 49$

Female $\quad 59$

Female 28

Female 41

Male $\quad 50$

Female $\quad 50$

Male $\quad 40$

Female

Female

Male

Female

Male

Female

Female

Female

Female

Female

Male

Female

Female

Female

Female

Male

Female

Female

Male

Female

Female

Female

Female

Female

Female

Male

Female

Female
Monostotic

Polyostotic

Polyostotic

Polyostotic

Polyostotic

Polyostotic

Polyostotic

Polyostotic

Polyostotic

Polyostotic

Polyostotic

Polyostotic

Polyostotic

Polyostotic

Monostotic

Polyostotic

Polyostotic

Polyostotic

Monostotic

Polyostotic

Polyostotic

Polyostotic

Polyostotic

Polyostotic

Polyostotic

Polyostotic

Monostotic

Polyostotic

Monostotic

Polyostotic

Polyostotic

Monostotic

Monostotic

Polyostotic

Polyostotic

Polyostotic

Polyostotic

Polyostotic

Polyostotic

Polyostotic

Polyostotic

Monostotic

Polyostotic

Polyostotic

Polyostotic

Monostotic

Polyostotic

Polyostotic

Monostotic

Polyostotic
Multiple

Multiple

Single

Single

Multiple

Multiple

Single

Multiple

Multiple

Multiple

Single

Multiple

Multiple

Multiple

Multiple

Multiple

Multiple

Multiple

Single

Single

Single

Single

Multiple

Multiple

Single

Multiple

Multiple

Single

Multiple

Multiple

Single

Single

Single

Multiple

Multiple

Multiple

Single

Multiple

Multiple

Single

Single

Multiple

Multiple

Multiple

Single

Single

Multiple

Multiple

Multiple

Multiple
R-L

B-U/B-L

R-L

R-L

R-U'R-L

B-U/B-L

B-U/B-L

B-U/B-L

B-U/B-L'H\&N

B-U/B-L

B-U/B-L

R-L

R-L

B-U/B-L'H\&N

L-L

B-U/B-L

B-L

L-U/L-L

B-U/B-L

B-U'H\&N

R-L

R-L

R-U

L-L

B-U/B-L

R-L

B-U/B-L

R-L

R-U'H\&N

B-L

B-L

L-L

R-L'H\&N

B-U/B-L'H\&N

L-L

R-L

R-L

B-U/B-L

L-L

R-L

B-U/B-L

L-U'R-L

R-L

B-L 
Table I. Continued.

\begin{tabular}{|c|c|c|c|c|c|}
\hline \multirow[b]{2}{*}{ First author/s, year (ref.) } & \multirow[b]{2}{*}{ Gender } & \multirow[b]{2}{*}{ Age, years } & \multicolumn{2}{|c|}{ Details of lesion } & \multirow[b]{2}{*}{ Lesion localization } \\
\hline & & & Fibrous dysplasia & Myxoma & \\
\hline \multirow[t]{7}{*}{ Iwasko, 2002 (55) } & Female & 39 & Polyostotic & Multiple & L-L \\
\hline & Female & 39 & Polyostotic & Multiple & B-U/B-L'H\&N \\
\hline & Female & 63 & Polyostotic & Multiple & B-L \\
\hline & Female & 52 & Monostotic & Multiple & R-U'R-L \\
\hline & Male & 49 & Polyostotic & Single & L-L \\
\hline & Female & 65 & Polyostotic & Single & \\
\hline & Female & 56 & Polyostotic & Single & $\mathrm{R}-\mathrm{U}$ \\
\hline Tsitouridis, 2002 (56) & Female & 28 & Polyostotic & Single & B-U/B-L'H\&N \\
\hline Fang, 2003 (57) & Male & 33 & Polyostotic & Single & $\mathrm{R}-\mathrm{L}$ \\
\hline Jhala, 2003 (58) & Female & 44 & Polyostotic & Multiple & $\mathrm{R}-\mathrm{U}$ \\
\hline Kabukcuoglu, 2004 (19) & Female & 52 & Polyostotic & Single & L-L \\
\hline Nguyen and Ram, 2005 (59) & Male & 48 & Polyostotic & Multiple & $\mathrm{R}-\mathrm{U}$ \\
\hline \multirow[t]{2}{*}{ Endo, 2007 (75) } & Male & 64 & Monostotic & Single & R-L \\
\hline & Female & 64 & Monostotic & Single & $\mathrm{R}-\mathrm{L}$ \\
\hline \multicolumn{6}{|l|}{ Miyake, 2006 (9) } \\
\hline Martin, 2007 (60) & Female & 52 & Polyostotic & Multiple & L-L \\
\hline McLaughlin, 2007 (61) & Female & 53 & Polyostotic & Single & $\mathrm{L}-\mathrm{U}$ \\
\hline Singnurkar, 2007 (62) & Male & 42 & Polyostotic & Multiple & $\mathrm{H} \& \mathrm{~N}$ \\
\hline Calisir, 2007 (63) & Female & 65 & Monostotic & Multiple & L-L \\
\hline MacFarlane, 2007 (64) & Male & 45 & Polyostotic & Multiple & B-U/B-L \\
\hline Schepers, 2008 (65) & Male & 35 & Polyostotic & Single & L-U \\
\hline Santos, 2008 (66) & Male & 48 & Polyostotic & Single & $\mathrm{H} \& \mathrm{~N}$ \\
\hline Zhao, 2008 (10) & Female & 60 & Monostotic & Single & R-L \\
\hline \multicolumn{6}{|l|}{ Beele, 2008 (15) } \\
\hline Tagliafico, 2009 (67) & Female & 40 & Polyostotic & Single & L-L \\
\hline Crawford, 2009 (12) & Male & 63 & Polyostotic & Single & $\mathrm{R}-\mathrm{U}$ \\
\hline \multicolumn{6}{|l|}{ Tang, 2009 (16) } \\
\hline Zoccali, 2009 (14) & Female & 32 & Polyostotic & Single & $\mathrm{R}-\mathrm{L}$ \\
\hline Arishima, 2010 (3) & Female & 71 & Monostotic & Single & L-L \\
\hline Case, 2010 (68) & Female & 69 & Polyostotic & Single & L-U \\
\hline Ijpma, 2010 (69) & Female & 51 & Polyostotic & Single & B-L \\
\hline Kitagawa, 2011 (20) & Female & 49 & Polyostotic & Multiple & B-U \\
\hline van der Wal, 2011 (70) & Female & 49 & Polyostotic & Single & L-L \\
\hline \multicolumn{6}{|l|}{ Yang, 2011 (17) } \\
\hline Gaumétou, 2012 (71) & Male & 56 & Polyostotic & Multiple & B-L \\
\hline Schimmöller, 2012 (72) & Female & 40 & Monostotic & Multiple & $\mathrm{L}-\mathrm{U}$ \\
\hline \multirow[t]{2}{*}{ John, 2013 (73) } & Female & 25 & Polyostotic & Multiple & B-U/B-L \\
\hline & Female & 25 & Polyostotic & Single & L-L \\
\hline Munksgaard, 2013 (18) & Female & 54 & Polyostotic & Multiple & B-L \\
\hline Tsourdi, 2013 (74) & Female & 45 & Polyostotic & Single & B-L \\
\hline Present study & Male & 38 & Monostotic & Single & $\mathrm{H} \& \mathrm{~N}$ \\
\hline
\end{tabular}

R-L, right lower limbs; B-U/B-L, bilateral upper limbs/bilateral lower limbs; L-L, left lower limbs; L-U, left upper limbs; R-U, right upper limbs; H\&N, head and neck.

The clinical presentation of MS is similar to that of fibrous dysplasia and intramuscular myxoma. Myxoma may be diagnosed in adolescents or young adults with symptoms, but fibrous dysplasia is incidentally found on imaging studies. In a series of 66 patients, Zoccali et al (14) reported that the myxoma develops
12 years prior to the fibrous dysplasia diagnosis. Intramuscular myxoma is a rare, benign tumor of the musculoskeletal system, with a low incidence. The tumor may occur in isolation or in association with fibrous dysplasia or McCune-Albright syndrome (21). Pain and facial palsy are uncommon. The tumor 
can occur at any location and tends to involve the large muscles of the thighs, followed by the buttocks, arms, and chest wall and shoulders. The majority of intramuscular myxomas are two or more, painless, palpable masses that are firm, slightly movable and discrete. Moreover, the myxomas are most typically located in the are of the bone lesions (21). Fibrous dysplasia of the bone is a disease that is characterized by bone deformities, pain and pathological fractures. Patients can, however, be asymptomatic. Fibrous dysplasia can involve one bone (monostatic) or several bones (polyostotic) (80). There are few conditions which present as a solitary intramuscular mass in association with monostotic fibrous dysplasia. MS occurs at a younger age, may be associated with additional symptoms (café-au-lait spots and endocrine dysfunction) (81) and is often operable. The patient may also experience a long survival time with the tumor.

Imaging is useful in the verification of the lesions, particularly for the diagnosis of fibrous dysplasia. Ultrasound examination is safe for the patient and is necessary for the diagnosis of intramuscular myxoma. The typical ultrasound features of MS are considered to be well-defined, hypoechoic masses that are formed from numerous small, fluid-filled spaces that join to form a microcystic pattern (22). CT scans, particularly coronal view scans, are useful in determining the size and quantity of fibrous dysplasia lesions, as well as verifying any bony involvement.

The optimal treatment for MS is surgical excision. Although MS is a benign tumor, it has a tendency to recur, with an accompanying risk of malignant transformation if incompletely excised and commonly requiring 'second-look' surgery (82). The rate of recurrence depends on the surgical approach. The surgical treatment of fibrous dysplasia is mostly indicated where there are progressive deformities, or a risk of fracture or pathological fracture. When the lesions occur in the jaw, the main aim of surgery is tumor resection, with good safety margins, and the reconstruction of the resultant defect, as this is important for the aesthetics and function of the oral and maxillofacial region (83). In the present case, free fibular osteocutaneous flap reconstruction was performed. For myxoma, a total excision is necessary and curative (84). When excluding differentials, such as primary malignancy or metastatic tumors, a full histopathological investigation should be performed for the lesions.

The precise etiology of fibrous dysplasia in association with myxoma remains unclear. The $\mathrm{G}$ protein/cAMP/adenylate cyclase signaling pathway that is central to the tissues involved in MAS led to the conclusion that regulatory Gs $\alpha$ protein (encoded by the GNAS gene) mutations were the underlying molecular etiology of MS (84). This theory is gradually becoming accepted.

In conclusion, clinicians should be aware of Mazabraud's syndrome in order to successfully manage patients with fibrous dysplasia in association with soft tissue myxomas and prevent misdiagnosis of this benign clinical entity as a malignant condition. In addition, differential diagnosis must be continued during clinical treatment when evaluating intramuscular lesions in the context of associated fibrous dysplasia.

\section{References}

1. Yaligod V and Ajoy SM: Intramuscular myxoma - a rare tumor. J Orthop Case Rep 3: 38-41, 2013.
2. Chapurlat RD and Meunier PJ: Fibrous dysplasia of bone. Best Pract Res Clin Rheumatol 14: 385-398, 2000.

3. Segev Z and Reiner S: Intramuscular myxoma associated with fibrous dysplasia of adjacent bone. Harefuah 108: 493-494, 1985 (In Hebrew).

4. Arishima Y, Setoguchi T, Abematsu M, Tominaga H, Fukunaga E and Komiya S: Mazabraud's syndrome with solitary myxoma and monostotic fibrous dysplasia. J Orthop Sci 15: 144-147, 2010

5. Braunwarth K: Simultaneous occurrence of fibrous dysplasia with extraosseous fibromyxomas. Fortschr Geb Rontgenstr 78: 589-594, 1953 (In German).

6. Berkhoff WB, ter Bruggen Hugenholtz FI and Ingenhoes $\mathrm{R}$ : A patient with multiple intramuscular myxomas as an extra-osseous manifestation of fibrous dysplasia. Ned Tijdschr Geneeskd 125: 1460-1462, 1981 (In Dutch).

7. Limouzy F, Durroux R, Chiron P, Tricoire JL, Puget J and Utheza G: Fibrous dysplasia associated with intramuscular myxoma. Rev Chir Orthop Reparatrice Appar Mot 82: 336-339, 1996 (In French).

8. Struk DW, Munk PL and Lee MJ: Musculoskeletal case 8. Mazabraud's syndrome - intramuscular myxoma associated with fibrous dysplasia. Can J Surg 43: 15, 62-63, 2000.

9. Miyake M, Tateishi U, Maeda T, Arai Y, Seki K, Hasegawa T and Sugimura K: F-18 fluorodeoxyglucose positron emission tomography finding of Mazabraud syndrome. Clin Nucl Med 31: 627-629, 2006.

10. Zhao H, Zhang H and Jiang Z: Clinicopathological characteristics of Mazabraud syndrome. Lin Chuang Yu Bing Li Xue Za Zhi 24: 47-49, 2008 (In Chinese).

11. Logel RJ: Recurrent intramuscular myxoma associated with Albright's syndrome. J Bone Joint Surg Am 58: 565-568, 1976.

12. Henschen F: Fall von ostitis Fibrosa mit multiplen Tumoren in der umgebenden Muskulatur. Verh Dtsch Ges Pathol 21: 93-97, 1926 (In German).

13. Mazabraud A, Semat P and Roze R: Apropos of the association of fibromyxomas of the soft tissues with fibrous dysplasia of the bones. Presse Med 75: 2223-2228, 1967 (In French).

14. Zoccali C, Teori G, Prencipe U and Erba F: Mazabraud's syndrome: A new case and review of the literature. Int Orthop 33: 605-610, 2009.

15. Beele X, Delanote G, Buyse G and Claikens B: Mazabraud syndrome. JBR-BTR 91: 84-85, 2008.

16. Tang J, Zhao HY, Zheng L, Zhang HZ and Jiang ZM: Abnormal expression of c-myc, p53, p16 protein and GNAS1 gene mutation in fibrous dysplasia. Zhonghua Bing Li Xue Za Zhi 38: 292-297, 2009 (In Chinese).

17. Yang XD, Xu G, Lü B, Li K and Xu Y: Mazabraud syndrome: Report of a case. Zhonghua Bing Li Xue Za Zhi 40: 274-276, 2011 (In Chinese).

18. Munksgaard PS, Salkus G, Iyer VV and Fisker RV: Mazabraud's syndrome: Case report and literature review. Acta Radiol Short Rep 2: 2047981613492532, 2013.

19. Kabukcuoglu F, Kabukcuoglu Y, Yilmaz B, Erdem Y and Evren I: Mazabraud's syndrome: Intramuscular myxoma associated with fibrous dysplasia. Pathol Oncol Res 10: 121-123, 2004.

20. Kitagawa Y, Ishihara Y, Hayashi M, Kim Y, Fujii N and Ito H: Mazabraud syndrome associated with McCune-Albright syndrome. J Orthop Sci 16: 129-132, 2011.

21. Lopez-Ben R, Pitt MJ, Jaffe KA and Siegal GP: Osteosarcoma in a patient with McCune-Albright syndrome and Mazabraud's syndrome. Skeletal Radiol 28: 522-526, 1999.

22. Szendrói M, Rahóty P, Antal I and Kiss J: Fibrous dysplasia associated with intramuscular myxoma (Mazabraud's syndrome): A long-term follow-up of three cases. J Cancer Res Clin Oncol 124: 401-406, 1998.

23. Krogius A: A case of osteitis fibrosa with multiple fibromyxomatoesen muscle tumors. Acta Chir Scan 64: 465-471, 1928 (In German).

24. Uehlinger E: Osteofibrosis deformans juvenilis. (Polyostotische fibroise dysplasie Jaffé-Lichtenstein.). Virchows Arch Path Anat 306: 255-299, 1940 (In German).

25. Mazabraud A and Girard J: A peculiar case of fibrous dysplasia with osseous and tendinous localizations. Rev Rhum Mal Osteoartic 24: 652-659, 1957 (In French).

26. Heinemann G and Worth D: Zur Osteofibrosis deformans juvenilis. Bruns Beitr Klin Chir 197: 327-336, 1958 (In German).

27. Laporte F, Leger H and Malchair G: Albright's syndrome. J Chir (Paris) 82: 457-475, 1961 (In French). 
28. Lick RF and Viehweger G: A contribution to the diagnosis of fibrous dysplasia of the skeletal system (Jaffe-Lichtenstein-Uehlinger). A roentgenological and pathologic anatomical study. Fortschr Geb Rontgenstr Nuklearmed 97: 33-38, 1962 (In German).

29. Roze R, Mazabraud A and Semat P: Fibrous dysplasia of bone and myxomas of the soft tissues. Localized sarcomatous degeneration. J Radiol Electrol Med Nucl 48: 527-536, 1967 (In French).

30. Semat P, Roze R and Mazabraud A: Fibrous dysplasia of bone associated with soft tissue myxma. J Radiol Electrol Med Nucl 50: 287-292, 1969 (In French).

31. Wirth WA, Leavitt D and Enzinger FM: Multiple intramuscular myxomas. Another extraskeletal manifestation of fibrous dysplasia. Cancer 27: 1167-1173, 1971.

32. Lejeune E, Bouvier M, Vauzelle JL, Queneau P, Thomas JD, Chaudy J, Leung TK and Deplante JP: Fibrous dysplasia and soft tissue myxomas. Rev Rhum Mal Osteoartic 39: 281-288, 1972 (In French)

33. Ireland DC, Soule EH and Ivins JC: Myxoma of somatic soft tissues. A report of 58 patients, 3 with multiple tumors and fibrous dysplasia of bone. Mayo Clin Proc 48: 401-410, 1973.

34. Sedmak DD, Hart WR, Belhobek GH and Marks KE: Massive intramuscular myxoma associated with fibrous dysplasia of bone. Cleve Clin Q 50: 469-472, 1983.

35. Lever EG and Pettingale KW: Albright's syndrome associated with a soft-tissue myxoma and hypophosphataemic osteomalacia. Report of a case and review of the literature. J Bone Joint Surg Br 65: 621-626, 1983

36. Witkin GB, Guilford WB and Siegal GP: Osteogenic sarcoma and soft tissue myxoma in a patient with fibrous dysplasia and hemoglobins JBaltimore and S. Clin Orthop Relat Res 204 245-252, 1986

37. Blasier RD, Ryan JR and Schaldenbrand MF: Multiple myxomata of soft tissue associated with polyostotic fibrous dysplasia. A case report. Clin Orthop Relat Res 206: 211-214, 1986.

38. Biagini R, Ruggieri P, Boriani S and Picci P: The Mazabraud syndrome: Case report and review of the literature. Ital J Orthop Traumatol 13: 105-111, 1987.

39. Glass-Royal MC, Nelson MC, Albert F, Lack EE and Bogumill GP: Case report 557: Solitary intramuscular myxoma in a patient with polyostotic fibrous dysplasia. Skeletal Radiol 18 392-398, 1989.

40. Sundaram M, McDonald DJ and Merenda G: Intramuscular myxoma: A rare but important association with fibrous dysplasia of bone. AJR Am J Roentgenol 153: 107-108, 1989.

41. Gianoutsos MP, Thompson JF and Marsden FW: Mazabraud's syndrome: Intramuscular myxoma associated with fibrous dysplasia of bone. Aust N Z J Surg 60: 825-828, 1990.

42. Prayson MA and Leeson MC: Soft-tissue myxomas and fibrous dysplasia of bone. A case report and review of the literature. Clin Orthop Relat Res 291: 222-228, 1993.

43. Gober GA and Nicholas RW: Case report 800: Skeletal fibrous dysplasia associated with intramuscular myxoma (Mazabraud's syndrome). Skeletal Radiol 22: 452-455, 1993.

44. Aoki T, Kouho H, Hisaoka M, Hashimoto H, Nakata H and Sakai A: Intramuscular myxoma with fibrous dysplasia: A report of two cases with a review of the literature. Pathol Int 45: 165-171, 1995.

45. Fujii K, Inoue M, Araki Y and Ishida O: Multiple intramuscular myxomas associated with polyostotic fibrous dysplasia. Eur J Radiol 22: 152-154, 1996.

46. Court-Payen M, Ingemann Jensen L, Bjerregaard B, Schwarz Lausten G and Skjoldbye B: Intramuscular myxoma and fibrous dysplasia of bone - Mazabraud's syndrome. A case report. Acta Radiol 38: 368-371, 1997.

47. Cabral CE, Guedes P, Fonseca T, Rezende JF, Cruz Júnior LC and Smith J: Polyostotic fibrous dysplasia associated with intramuscular myxomas: Mazabraud's syndrome. Skeletal Radiol 27: 278-282, 1998

48. Thomachot B, Daumen-Legre V, Pham T, Acquaviva PC and Lafforgue P: Fibrous dysplasia with intramuscular myxoma (Mazabraud's syndrome). Report of a case and review of the literature. Rev Rhum Engl Ed 66: 180-183, 1999.

49. Walker RE, Schwartz RK and Gale DR: Musculoskeletal case of the day. Mazabraud's syndrome (intramuscular myxomas associated with fibrous dysplasia of bone). AJR Am J Roentgenol 173: 797, 800-802, 1999.

50. Kransdorf MJ and Murphey MD: Diagnosis please. Case 12: Mazabraud syndrome. Radiology 212: 129-132, 1999.
51. Okamoto S, Hisaoka M, Ushijima M, Nakahara S, Toyoshima S and Hashimoto H: Activating Gs(alpha) mutation in intramuscular myxomas with and without fibrous dysplasia of bone. Virchows Arch 437: 133-137, 2000.

52. Faivre L, Nivelon-Chevallier A, Kottler ML, Robinet C, Khau Van Kien P, Lorcerie B, Munnich A, Maroteaux P, Cormier-Daire V and LeMerrer M: Mazabraud syndrome in two patients: Clinical overlap with McCune-Albright syndrome. Am J Med Genet 99: 132-136, 2001.

53. Delabrousse E, Couvreur M, Bartholomot B, Lucas X and Kastler B: Mazabraud syndrome: A case diagnosed with MRI. J Radiol 82: 165-167, 2001 (In French).

54. Pollandt K, Lohmann CH, Werner M and Delling G: Clinical pathological aspects of Mazabraud's syndrome. Pathologe 23: 357-360, 2002 (In German).

55. Iwasko N, Steinbach LS, Disler D, Pathria M, Hottya GA, Kattapuram S, Varma DG and Kumar R: Imaging findings in Mazabraud's syndrome: Seven new cases. Skeletal Radiol 31: 81-87, 2002.

56. Tsitouridis I, Sayegh FE, Natsis K, Goutsaridou F, Melidis D and Emmanouilidou M: Mazabraud's syndrome: MRI evaluation. Eur J Radiol Extra 45: 83-87, 2003.

57. Fang AS, Riley G, Huang SJ and O'Donnell RJA: A 35-year-old man with bony deformities and a soft tissue mass. Clin Orthop Relat Res 417: 313-320, 2003.

58. Jhala DN, Eltoum I, Carroll AJ, Lopez-Ben R, Lopez-Terrada D, Rao PH, Pettenati MJ and Siegal GP: Osteosarcoma in a patient with McCune-Albright syndrome and Mazabraud's syndrome: A case report emphasizing the cytological and cytogenetic findings. Hum Pathol 34: 1354-1357, 2003.

59. Nguyen BD and Ram PC: Mazabraud's syndrome with sarcomatous transformation: Scintigraphic and radiologic imaging. Clin Nucl Med 30: 829-830, 2005

60. Martin S, Rapariz JM, Osés MJ and Martinez C: A possible cause of multiple intramuscular masses: Mazabraud's syndrome (2007: 11b). Eur Radiol 18: 417-421, 2008.

61. McLaughlin A, Stalley P, Magee M, Soper J and Van der Wall H: Correlative imaging in an atypical case of Mazabraud syndrome. AJR Am J Roentgenol 189: W353-W356, 2007.

62. Singnurkar A, Phancao JP, Chatha DS and Stern J: The appearance of Mazabraud's syndrome on 18F-FDG PET/CT. Skeletal Radiol 36: 1085-1089, 2007.

63. Calisir C, Inan U, Yavas US, Isiksoy S and Kaya T: Mazabraud's syndrome coexisting with a uterine tumor resembling an ovarian sex cord tumor (UTROSCT): A case report. Korean J Radiol 8: 438-442, 2007.

64. Macfarlane P, Lew W and Neuhaus S: An aggressive case of Mazabraud's syndrome. Eur J Surg Oncol 33: 1087-1089, 2007.

65. Schepers S, Brys P and Samson I: Case 6532. Mazabraud's Syndrome. http://www.eurorad.org/eurorad/case.php?id=6532. Accessed May 8, 2008.

66. Santos CT, Choo CT and Loh AH: Orbital fibrous dysplasia with soft tissue hamartoma - a variant of Mazabraud's syndrome. Orbit 27: 207-209, 2008

67. Tagliafico A, Succio G, Martinoli C and Serafini G: Clinical overlap between Mazabraud and McCune-Albright syndromes. J Ultrasound Med 28: 397-399, 2009.

68. Case DB, Chapman CN Jr, Freeman JK and Polga JP: Best cases from the AFIP: Atypical presentation of polyostotic fibrous dysplasia with myxoma (Mazabraud syndrome). Radiographics 30: $827-832,2010$

69. IJpma FF, Moll FC, Mostert AK, Flach HZ and de Vries JE: Mazabraud syndrome - benign intramuscular myxoma with fibrous skeletal dysplasia. Ned Tijdschr Geneeskd 155: A2513, 2011 (In Dutch).

70. van der Wal WA, Unal H, de Rooy JW, Flucke U and Veth RP: Fibrous dysplasia of bone associated with soft-tissue myxomas as well as an intra-osseous myxoma in a woman with Mazabraud's syndrome: A case report. J Med Case Reports 5: 239, 2011.

71. Gaumétou E, Tomeno B and Anract P: Mazabraud's syndrome. A case with multiple myxomas. Orthop Traumatol Surg Res 98: 455-460, 2012.

72. Schimmöller L, Lehwald N, Antoch G and Kröpil P: Polyostotic fibro-osseus lesions associated with intramuscular soft tissue neoplasms. Radiologe 52: 934-936, 2012 (In German).

73. John AM, Behera KK, Mathai T, Parmar Hand Paul TV: Mazabraud syndrome. Indian J Endocrinol Metab 17: 740-742, 2013.

74. Tsourdi E, Hamann C and Hofbauer LC: Skeletal and soft tissue involvement in Mazabraud syndrome. J Clin Endocrinol Metab 98: E1381-E1382, 2013. 
75. Endo M, KawaiA, Kobayashi E, et al: Solitary intramuscular myxoma with monostotic fibrous dysplasia as a rare variant of Mazabraud's syndrome. Skeletal Radiol 36: 523-529, 2007. Crawford EA, Brooks JS and Ogilvie CM: Osteosarcoma of the proximal part of the radius in Mazabraud syndrome. A case report. J Bone Joint Surg Am 91: 955-960, 2009.

76. Enzinger FM: Intramuscular myxoma: A review and follow-up study of 34 cases. Am J Clin Pathol 43: 104-113, 1965.

77. Lichtenstein L and Jaffé HL: Fibrous dysplasia of bone. Arch Pathol (Chic) 33: 777-816, 1942.

78. Alves C and Silva SF: Partial benefit of anastrozole in the long-term treatment of precocious puberty in McCune-Albright syndrome. J Pediatr Endocrinol Metab 25: 323-325, 2012.

79. Adetayo OA, Salcedo SE, Borad V, Richards SS, Workman AD and Ray AO: Fibrous dysplasia: An overview of disease process, indications for surgical management, and a case report. Eplasty 15: e6, 2015.
80. Fornage BD and Romsdahl MM: Intramuscular myxoma: Sonographic appearance and sonographically guided needle biopsy. J Ultrasound Med 13: 91-94, 1994.

81. He Y, Zhang ZY, Zhu HG, Sader R, He J and Kovacs AF: Free fibula osteocutaneous flap for primary reconstruction of T3-T4 gingival carcinoma. J Craniofac Surg 21: 301-305, 2010.

82. Dreizin D, Glen C and Jose J: Mazabraud syndrome. Am J Orthop (Belle Mead NJ) 41: 332-335, 2012.

83. Coloma J, García E and Rodríguez A: Intramuscular myxoma. Report of three cases. Acta Ortop Mex 28: 244-247, 2014.

84. Walther I, Walther BM, Chen Y and Petersen I: Analysis of GNAS1 mutations in myxoid soft tissue and bone tumors. Pathol Res Pract 210: 1-4, 2014. 